\title{
INTRODUCTION TO VITAHUMANOLOGY
}

\author{
(C) Vladimir M. Evstropov, Galina A. Zelenkova
}

\author{
Don State Technical University, Rostov-on-Don, Russian Federation \\ v.evstr@mail.ru, zelenkovalex@rambler.ru
}

If we talk about sciences in one way or another related to the human research, then it is necessary to take into account that in the subject of research all sciences are divided into natural, humanitarian and technical. Despite some specifics, there is a specialization and an integration in all these sciences. Nevertheless, the problematic nature of the orientation of modern science initiated the development of interdisciplinary and complex researches. Based on the fact that the fundamental feature of the human from all living beings is his differences in interaction with the environment, it becomes relevant, from our point of view, to emphasize the study of the human in an interdisciplinary aspect from the point of view of his productive, creative life activity, which is becoming more and more extensive and at the same time unsafe. Therefore, it is important to reflect characteristics reflecting physiological and psychophysiological features of a person's activity when systematically assessing his natural-humanitarian characteristics. In this regard, it seems advisable for us to describe the essence of the doctrine of vitahumanology briefly (Vita - life (Latin), human - human (English), logos - thought (Greek)). Due to the fact that an essential component of human life is his activity, vitahumanology can be considered as one of the fields of biosociology, studying physiological, psychophysiological and noxological aspects of human activity in the environment. Such fields of knowledge as ecology, hygiene, labor psychology, labor physiology, ergonomics, etc. can play a connecting role between scientific and humanitarian. Vitahumanology can be considered as one of the fields of biosociology, aimed at the systemically oriented and integrative study of biological-social, medico-social, medico-preventive, noxological and psychological foundations of human life and activity in the environment and in the production environment.

Key words: human ecology, environment, human, integrity, interdisciplinary, natural, humanitarian and technical sciences.

\section{[В.М. Евстропов, Г.А. Зеленкова Введение в витагуманологию]}

Если говорить о науках, так или иначе связанных с исследованием человека, то необходимо принимать во внимание, что по предмету исследования все науки делятся на естественные, гуманитарные и технические. Но несмотря на их некоторую специфику, во всех этих науках наблюдается специализация и интеграция. Тем не менее, проблемный характер ориентации современной науки инициировал развёртывание междисциплинарных и комплексных исследований. Исходя из того что принципиальной особенностью человека от всех живых существ, являются его отличия по взаимодействию с окружающей средой, актуальным, с нашей точки зрения, становится акцентирование изучения человека в междисциплинарном аспекте с позиций его производственной, созидательной жизнедеятельности, которая становится все более обширной и одновременно небезопасной. Поэтому важно при системной оценке естественно-гуманитарных характеристик человека отразить также характеристики, отражающие физиологические и психофизиологические особенности его деятельности. В этой связи нам представляется целесообразным кратко охарактеризовать сущность учения о витагуманологии (лат. vita - жизнь, англ. human-человек, греч. логос - мысль). В связи с тем, что существенной составляющей жизни человека является его деятельность, витагуманология, может рассматриваться как одно из направлений биосоциологии, изучающее физиологические, психофизиологические и ноксологические аспекты деятельности человека в окружающей среде. Коннектирующую роль между естественно-научным, гуманитарным могут выполнять такие области знаний как экология, гигиена, психология труда, физиология труда, эргономика и т.д. Витагуманология может рассматриваться как одно из направлений биосоциологии, направленное на системно-ориентированное и интегративное изучение биолого-социальных, медико-социальных, медико-профрилактических, ноксологических и психологических основ жизни и деятельности человека в окружающей и производственной среде.

Ключевые слова: экология человека, окружающая среда, человек, интегративность, междисциплинарность, естественные, гуманитарные и технические науки. 
Vladimir M. Evstropov - M.D., Associate Professor, Don State Technical University, Rostov-on-Don, Russian Federation.

Galina A. Zelenkova - Ph.D. (Advanced Doctorate) in Agricultural sciences, Professor, Rostov-on-Don, Russian Federation.

Евстропов Владимир Михайлович - доктор медицинских наук, доцент, Донской государственный технический университет, г. Ростов-на-Дону, Российская Федерация.

Зеленкова Галина Александровна - доктор сельскохозяйственных наук, профрессор, Донской государственный технический университет, г. Ростов-на-Дону, Российская Федерация.

One of the features of the modern stage of the science development is a qualitatively new type of ontological consideration of life in the philosophy of science, as an objective "inner world" of the human studied not only by social and humanitarian disciplines, but also by biological and medical sciences.

If we talk about the sciences, somehow related to the research of the human, then it is necessary to take into account that in the subject of the research all sciences are divided into natural, humanitarian and technical. Natural sciences study the human as a material, biological being, and humanitarian sciences (history, law, economics, etc.) specialize in the human and his life activities in the society. In technical sciences, the relationship between natural and humanitarian sciences is largely manifested. But, despite some specifics, there is a specialization and an integration in all these sciences.

L.F. Ilyichyov with coauthors consider the division of scientific disciplines, forming in their entirety a system of science in general, on three big groups (natural, social and technical sciences) to be rather conditional. There is no significant difference between these subsystems, some scientific disciplines are intermediate [8].

The statement of existence of certain differences between natural and humanitarian sciences doesn't exclude the possibility of unity between them in their direct interaction. Strengthening integration processes between these sciences is caused by the existence of direct connections between natural and humanitarian sciences and the general methods of the research.

Although interdisciplinary and intersubjectivity between two types of general scientific theories (humanitarian sciences and natural science) is quite obvious, K.A. Khadartseva and coauthors note the problem of closer interaction of accurate humanitarian knowledge at the level of convergence. At the same time, the transition stage in this convergence is the science of living systems (biology, medicine, ecology), which according to the general researches and methods occupy an intermediate place between humanitarian sciences and natural science [10].

According to A.P. Sadokhin, the human problem has got an interdisciplinary character, and the modern natural-scientific view of the human is a complex and multidimensional knowledge obtained within the framework of various disciplines. A holistic view of the human, his essence and nature, is impossible without attracting data of humanitarian and social knowledge [6].

Complex, historically developing systems, which include the human, take a growing part in modern post-nonclassical science. They include objects of modern biotechnology, primarily genetic engineering, biomedical objects, large ecosystems and the biosphere as a whole, human-machine systems, including artificial intelligence systems, social objects, etc. In a broad sense, they can include any complex synergistic systems, the interaction with which turns the human action itself into a component of the system. The methodology 
of the study of such objects brings natural-scientific and humanitarian knowledge closer, forming the basis for their deep integration.

Sociobiology studies all forms of social behavior of living beings, including the human, based on the principles of genetics and evolutionary biology [9]. It is considered as a field in philosophy and sociology, aiming to implement a new synthesis between biology and sciences of the human and the society. In sociobiology, such fundamental issues as the relationship between biological and social, physiological and psychological, genetically conditioned and acquired in nature and human development are discussed. Sociobiology can also be considered as a kind of the body of knowledge that arose on the basis of population genetics, evolutionary theory, ethology, ecology.

Biosociology is an emerging scientific concept of an interdisciplinary nature and a practice of studying complex by nature phenomena of modern social life, proceeds from the inextricable connection of biological and social components in human life and social communities. It reveals possible transformations of the society by studying the accumulation in new generations of a critical mass of biological and intellectual and sociocultural changes. Biosociology studies the links between biological and social phenomena, processes in living systems of communities of the animals, the human and the society [5]. The study of the human is central to biosociology, since it considers the human as a living system in its unity of physical and spiritual, natural and social, hereditary and lifetime acquired. On the one hand, the human obeys biological (biophysical, biochemical, physiological) laws. On the other hand, from the standpoint of conscious psyche and personality, the human is connected with social life of the society [7].

According to M.N. Epstein, humanology builds its ideas about the human on the basis of his ability to self-alienation, to create self-acting cybernetic creatures and algorithms of the artificial intelligence. Techno-human is located in the center of humanology, which perceives the human in transformations that take him beyond the boundaries of biological nature. The artificial intelligence of human creations is also considered as a field of humanology. Humanology introduces a new paradigm into the humanitarian sciences: the human, in his difference from other forms of intelligence, stands out from the circle of traditional humanitarian sciences, in this connection it positions itself as a new science of the human [12]. I.A. Shevnina understands humanology as a science of the human who crosses his species boundaries, about human transformations in the process of creating artificial forms of life and intelligence, potentially exceeding the capabilities of a biological species of the human. Humanology studies the human as a part of the technosphere, as one of the types of intelligent beings, the "bio species" (an intelligent organism), along with possible "techno species" (intelligent mechanisms). This is its significant difference from anthropology [11].

S.V. Valtsev considers that homology cannot be the new human science due to the dominance of its biology. Neither anthropology, nor philosophical anthropology, nor humanology can claim the role of the human science [1]. The author proposes to give the doctrine of the human a term "homology" (homo - human (Latin) and logic - doctrine (Greek)). In his opinion, the main problems and fields of research may be the following: the essence of the human, the species-specific characteristic of the human and his specific differences in comparison with others, with the animal world and the world of artificial intelligence, the specifics and boundaries of human knowledge, the criterion of the truth of human knowledge of himself and the actual reality, etc.

The natural sciences that study the features of the structure and functioning of the human body include cytology, human anatomy and physiology, medicine, etc. However, based on the fact that fundamental features of the human from all living beings are his differences in interaction with the environment [3], it becomes relevant, from our point of view, to emphasize the study of the human from the point of view of his productive, crea- 
tive life activities, which is becoming more and more extensive and at the same time unsafe. Therefore, it is very important, from our point of view, when systematically assessing the natural-humanitarian features of the human, to reflect also the characteristics that reflect the physiological and psychophysiological characteristics of his activities.

In this regard, it seems advisable for us to describe the essence of the doctrine of vitahumanology briefly (vita - life (Latin), human - human (English), logos - thought (Greek)). Considering that the essential component of human life is his activity, which can be reflected in the form of a communicative way of functioning of organisms, vitahumanology, from our point of view, can be considered as one of the fields of biosociology that studies the human from the standpoint of a living system in its unity of physical and spiritual, natural and social, inherited and acquired for the life term.

Unlike the well-known approaches to the human research (humanology, homology, sociology), vitahumanology is a biosociological approach to the human study, based on the methodological basis of sciences that study primarily physiological, psychophysiological and noxological aspects of his activities.

In our opinion, it is advisable to include in the system block of disciplines the following disciplines that form the doctrine of vitahumanology. The group of noxologically oriented disciplines can include both noxology itself and fields of knowledge close to it. Noxology studies material dangers and potential environmental threats for the human and for the society, health and safety studies dangers and ways to protect the human from them in his habitat. Human ecology explores the patterns of effects of natural, social and domestic, and production factors on the human.

Human ecology, which studies the patterns of effects of natural, social and domestic, and production factors on the human, from our point of view, can serve as a link between the group of noxological and groups of medical, social and medico-preventive disciplines. Medico-social and medico-preventive disciplines that study the effects of the environment on the body and measures to improve the health of the population include: social hygiene and health care organization; general hygiene, child and adolescent hygiene, nutrition hygiene, labor hygiene, communal hygiene and radiation hygiene; epidemiology, medical geography, etc. The similar role, but in relation to the technical sciences, can be played by geoecology, which studies the connections between living organisms, including the human, man-made structures and the geological environment, labor protection, etc.

Labor hygiene refers to the section of preventive medicine, which studies the influence of working conditions of the labor process and factors of the working environment on the human body for scientific justification of standards and methods for the prevention of occupational diseases.

Labor medicine is generally concerned with strengthening and preserving the highest degree of physical, mental and social well-being of workers in all professions; prevention of workers' health deviations caused by working conditions, protection of workers from risks caused by unfavorable working conditions, adaptation of work and each employee to labor [4].

Medical and biological disciplines go beyond medicine and they are mainly a part of the relevant biological sciences (human anatomy, histology, cytology, physiology, pathology, toxicology, medical microbiology and parasitology, etc.). The connective role for this group can be played by biomedicine, the subject of which is the human acting as a prototype for biosimulation and building models of any order.

Groups of noxological and biomedical disciplines connect such fields of knowledge as "Medical and biological foundations of life safety," "Prevention of occupational diseases". Prevention of occupational diseases includes a system of medical and non-medical measures aimed at preventing accidents at work, reducing the risk of developing health disorders of workers, preventing or slowing down the progression of diseases and reduc- 
ing adverse consequences. The medical and biological foundation of life safety is an integrative discipline that studies the interaction of the body and the external environment, and includes, among others, such sections as labor physiology and toxicology [2].

Human physiology, labor physiology, psychology (medical, pedagogical, social, developmental, differential, labor psychology, psychology for special needs) studies the conditions, ways and methods of scientifically grounded solution of practical problems in the field of functioning and formation of the human as a subject of labor. Ergonomics is usually understood as a scientific discipline that explores the interaction of the human and other elements of the system to ensure human well-being and optimize the overall performance of the system. This is a scientific and design discipline formed at the intersection of psychology, physiology, labor hygiene, biomechanics, anthropology and a number of technical sciences.

Thus, vitahumanology can be considered as one of the fields of biosociology, aimed at the systemically oriented and integrative study of biological-social, medico-social, medico-preventive, noxological and psychological foundations of human life and activity in the environment and in the production environment.

\section{Лumepamypa}

1. Вальцев С.В. Хомология. Очертания новой дисциплины // Проблемы современной науки и образования. 2012. № 3. С. 22-25.

2. Евстропов В.М. Медико-биологические аспекты безопасности жизнедеятельности в экстремальных и чрезвычайных ситуациях: монография. Ростов-наДону, 2013. 166 с.

3. Еникеев А.А. Философские вопросы естественных и технических наук (курс лекций): учебное пособие. Краснодар: КубГАУ, 2015. 50с.

4. Измеров Н.Ф., Боголепова Л.С. Сохранить и приумножить наследие гигиены труда // Гигиена труда и профрессиональные заболевания. 1980. № 4. С. 41-42.

5. Луков В.А. Биосоциология // Энциклопедия гуманитарных наук. 2011. №3. C.319-323.

6. Садохин А.П. Концепции современного естествознания: учебник для студентов вузов, обучающихся по гуманитарным специальностям и специальностям экономики и управления. М.: ЮНИТИ-ДАНА, 2006. 447 с.

7. Сопов Г.П., Овчинников В.И. Биосоциология как наука // Социальногуманитарные знания. 2010. №6. С.72-84.

8. Философский энциклопедический словарь. М.: Советская энциклопедия. Гл. ред.: Л.Ф. Ильичёв, П.Н. Федосеев, С. М. Ковалёв, В. Г. Панов.1983.840с.

9. Философия: Энциклопедический словарь / Под ред. А.А. Ивина. М.: Гардарики. 2004. 1072 c.

10. Хадарцева К.А., Джумагалиева Л.Б., Гудкова С.А., Кравченко Е.Н. Возможна ли конвергенция между гуманитарной наукой и биомедицинскими науками? // Сложность. Разум. Постнеклассика. 2014. №4. С. 62-72.

11. Шевнина И.А. Проблема деантропологизации и реконструкции человека в Российской фрилософии XXI века // Наука и современность. 2014. № 31. С. 175180.

12. Эпштейн М.Н. Творческое исчезновение человека. Введение в гуманологию // Человек. 2009. № 4. С.48-57. 


\section{References}

1. Valtsev S.V. Khomologiia. Ochertaniia novoi distsipliny. Problemy sovremennoi nauki i obrazovaniia [Homology. The outline of the new discipline. Problems of modern science and education]. 2012. No. 3. pp. 22-25 (in Russian).

2. Evstropov V.M. Mediko-biologicheskie aspekty bezopasnosti zhiznedeiatelnosti v ekstremalnykh i chrezvychainykh situatsiiakh: monografiia [Medical and biological aspects of life safety in extreme and emergency situations: monograph]. Rostov-onDon, 2013. 166 p. (in Russian).

3. Enikeev A.A. Filosofskie voprosy estestvennykh i tekhnicheskikh nauk (kurs lektsii): uchebnoe posobie [Philosophical issues of natural and technical sciences (lecture course): study guide]. Krasnodar: KubSAU, 2015. 50 p. (in Russian).

4. Izmerov N.F., Bogolepova L.S. Sokhranit i priumnozhit nasledie gigieny truda. Gigiena truda i professionalnye zabolevaniia [Preserve and multiply the legacy labor hygiene. Labor hygiene and occupational diseases]. 1980. No. 4. pp. 41-42 (in Russian).

5. Lukov V.A. Biosotsiologiia. Entsiklopediia gumanitarnykh nauk [Biosociology. Encyclopedia of humanitarian sciences]. 2011. No. 3. pp. 319-323 (in Russian).

6. Sadokhin A.P. Kontseptsii sovremennogo estestvoznaniia: uchebnik dlia studentov vuzov, obuchaiushchikhsia po gumanitarnym spetsial'nostiam i spetsialnostiam ekonomiki i upravleniia [Concepts of Modern Natural Science: a book for university students studying in humanitarian specialties and specialties of economics and management]. Moscow: UNITY-DANA, 2006. 447 p. (in Russian).

7. Sopov G.P., Ovchinnikov V.I. Biosotsiologiia kak nauka. Sotsialno-gumanitarnye znaniia [Biosociology as a science. Social and humanitarian knowledge]. 2010. No. 6. pp. 72-84 (in Russian).

8. Filosofskii entsiklopedicheskii slovar. Moscow: Sovetskaia entsiklopediia [Philosophical encyclopedical dictionary. Moscow: Soviet Encyclopedia]. Chief editor: L.F. Ilyichev, P.N. Fedoseev, S.M. Kovalev, V.G. Panov.1983. 840 p. (in Russian).

9. Filosofiia: Entsiklopedicheskii slovar [Philosophy: Encyclopedical dictionary]. Under the editorship of A.A. Ivin. Moscow: Gardariki. 2004. 1072 p. (in Russian).

10. Khadartseva K.A., Dzhumagalieva L.B., Gudkova S.A., Kravchenko E.N. Vozmozhna li konvergentsiia mezhdu gumanitarnoi naukoi i biomeditsinskimi naukami? Slozhnost. Razum. Postneklassika [Is convergence between humanitarian sciences and biomedical sciences possible? Complexity. Intelligence. Post non-classic]. 2014. No. 4. pp. 62-72 (in Russian).

11. Shevnina I.A. Problema deantropologizatsii i rekonstruktsii cheloveka v Rossiiskoi filosofii XXI veka. Nauka i sovremennost [The problem of the deanthropology and reconstruction of the human in the Russian philosophy of the 21st century. Science and modernity]. 2014. No. 31. pp. 175-180 (in Russian).

12. Epstein M.N. Tvorcheskoe ischeznovenie cheloveka. Vvedenie $\mathrm{v}$ gumanologiiu. Chelovek [The creative disappearance of the human. Introduction to Humanology. Human]. 2009. No. 4. pp. 48-57 (in Russian).

3 August, 2020 